\title{
The Analysis of Anti-Corruption Education in Kindergarten DEK Padang
}

\author{
Yayuk Rahayu \\ Early Childhood Education Department, Padang State University, Padang, Indonesia, yayukjambi78@ gmail.com
}

\begin{abstract}
Education can play a role in combating corruption indirectly through the association of learning materials with messages to be conveyed regarding anti-corruption values. Anti-corruption education for early childhood is one of learning in the form of characters includes nine anticorruption values. Corruption occurs when no values of a strong anticorruption through habituation instilled in the anti-corruption values are: honesty, caring, independent, responsibility, hard work, simple, bold, disciplined, fair. Prevention of corruption is not only the duty of the Corruption Eradication Commission (KPK) but also all elements of society. One of the strategic prevention of corruption is education This type of research is descriptive. The research was conducted in kindergarten DEK Padang. Learning corruption, carried out most often is frequency picture books, through songs and movies. The results of observations and interviews that the media seem to be more easily understood -Media the child in identifying values to shape the character of the anti-corruption corruption. Anticorruption learning should be done continuously and integrated with other learning Those materials. By analyzing the two classes that perform anti-corruption learning classes that perform continuous and integrated with other activities and understanding the changing character of the anti-corruption values better. The results of observations and interviews that the media seem to be more easily understood-Media the child in identifying values to shape the character of the anti-corruption corruption. Anticorruption learning should be done continuously and integrated with other learning Those materials. By analyzing the two classes that perform anti-corruption learning classes that perform continuous and integrated with other activities and understanding the changing character of the anti-corruption values better. The results of observations and interviews that the media seem to be more easily understood -Media the child in identifying values to shape the character of the anti-corruption corruption. Anticorruption learning should be done continuously and integrated with other learning Those materials. By analyzing the two classes that perform anti-corruption learning classes that perform continuous and integrated with other activities and understanding the changing character of the anti-corruption values better.
\end{abstract}

\section{Keywords: Anticorruption, Childhood, Learning Anti-corruption}

\section{INTRODUCTION}

Anti-corruption education is an education that is consistent with the character and humanistic education that began to aggressively discourse by the government. Anticorruption education is part of the process of moral formation of children and is also expected to be a major foundation in identity formation honest. If the anti-corruption education has become an orientation and learning objectives, then the school will be a place seeding a culture of honesty. The school will give birth to the next generation who are not only smart intellectually, emotionally, and spiritually, but also has the personality of character, integrity, and responsible (Manurung, 2012),

Corruption is a multi-dimensional problem is not only the law nor the social, economic, political, cultural and religious. To eradicate corruption requires multiple approaches through anti-corruption education through preventive strategies, and repressive different detective to find the best efforts to eradicate corruption. (Assegaf, 2015),

Anticorruption learning for early childhood, aims to familiarize good behavior early on. It begins with instilling the values of compassion (Pedagogy of Love), meet the basic needs of children. Child-friendly learning, as well as basic values forming the character of the child as an honest, caring, discipline, independence, responsibility, hard work, simple, bold, and fair. All are built through a process of internalization and constructive. Early childhood education is an important phase for the values of honesty in the child's life. Knowledge and teaching children receive early days of his life will be saved and recorded children and will affect his personality until he grew up. (Dewayanti, 2016)

According to (Suryana, 2017) early childhood learning should be able to provide opportunities for children to get the scientific learning process. This will affect the child's ability to think and insights as they continue their education to a 
higher level. Children who liked to imitate an early age, they will imitate what is seen and heard. Other positive experiences during social activities is the basic capital that is essential for future life (Mayar, 2013), To carry out anticorruption education to children aged then it must pay attention to the concept of learning in Kindergarten (TK), which refers to: (1 Maturity (Maturity), (2. Readiness (readiness), (3. Learning while doing (learning by doing), (4. Learning in the pack in the game (learning by playing), ( 5 . Learning is fun (Joyfull learning) (Suryana, Early Childhood Education (Theory and Practice of Education, 2013).

Anti-corruption education is an education program on corruption which aims to build and increase awareness of all elements of society to the dangers and consequences of corruption. Anti-corruption education is basically the establishment and strengthening of basic values that are expected to form the anti-corruption attitude to children at an early age (Montessori, 2012),

According to (Anttiroiko, 2014) that the characteristics of the people of Finland to prevent corruption is through a culture of honest and hard-working. Research result (Abramov, Ruslan A; Sokolov, Maxim S ;, 2016) that the fight against corruption is to build a kind of "virtuous triangle". Triangle should include environmental learning environment that values integrity, well-planned system of strategic management by the government that affective, transparent and accountable, as well as the system of public control over the work of education.

Education can be used to fight corruption through the internalisation of values or policies. The strategy could be used to eradicate corruption. The Corruption Eradication Commission (KPK) to take steps to prevent corruption through prevention strategies in synergy with educational institutions. Child's experience is cumulative in the sense of learning experiences occur, if the experience is not uncommon, it is extremely influential. Anti-corruption education is an education policy can no longer be postponed in a formal school. If implemented in the long-term anticorruption education will be able to contribute to the prevention of corruption. (Werdiningsih, Rini ;, 2016),

According to (Indrawati, 2015) Combating corruption takes the role of teacher or professor to begin to seriously play an active role through education in shaping the character of anti-corruption. Prevention efforts should be made as early as possible. based on (Law No.30 / 2002 on Corruption Eradication Commission) Article $13 \mathrm{C}$, which reads in "In carrying out the duties of prevention as referred to in Article $6 \mathrm{~d}$, the Corruption Eradication Commission authority to implement measures or preventive anti-corruption education programs at every level of education.

Once the importance of anti-corruption education in which education should start early because the time that children begin to learn from the values of the characters, especially honesty that will be the basis in life. Early childhood education is an important phase for the values of honesty in the child's life. Knowledge and teaching children receive early days of his life will be saved and recorded children and will affect his personality into adulthood. Children who grew up watching the frauds tend to form a false perception of moral values. This over time can result in the shifting of values in him. Not infrequently we see adults who commit corrupt behavior such as running red lights. If children cannot recognize the line between cheating and honesty, they will grow into a pragmatic and easily can be a negative influence. Through the anti-corruption education through learning will foster the values of honesty so as to foster trust. Honest child will grow into a child who is confident, trustworthy and happy. Internalize honesty in parenting Indonesia will create a society that is safe, comfortable, prosperous. The good life will be easily realized. Internalize honesty in parenting Indonesia will create a society that is safe, comfortable, prosperous. The good life will be easily realized. Internalize honesty in parenting Indonesia will create a society that is safe, comfortable, prosperous. The good life will be easily realized.

Under the anti-corruption education implemented through learning that is already implemented in kindergarten DEK Padang. Researchers wanted to see how far the frequency of learning methods and media used affects the understanding of the behaviors according to the indicator values of honesty and coherence with other anti-corruption values.

\section{METHODS}

This study was conducted by using descriptive analysis, the issues dealt with by the facts obtained in the field. According to (Bungin, 2011) that the descriptive method describes a variety of conditions, a variety of situations. Then lifted to the surface character or picture of the condition, situation or variable. Based on the above understanding the characteristics of the descriptive method in this research focuses on the analysis of the use of media and methods to change and character of the child containing the values of anti-corruption. Population taken from 30 children with different local in Kindergarten DEK Padang. The study starts from January to June 2018. Data collection technique structured observation method and interview. The purpose of this study as a literature on anti-corruption study conducted continuously by a variety of methods can alter the character of the child. Through this analysis determine the extent of anti-corruption education conducted Kindergarten DEK can be dispatched moral and character in children. Analysis of the data used in this study is the distribution of frequencies which is described by using charts.

\section{RESULTS AND DISCUSSION}

Analysis of the results of research conducted as a literature degree to which the media can shape the character of learning which are based on the values of anti-corruption education is the main anti-corruption planting the value of honesty in children. Those values associated with other values. The values of anticorruption consists of sections (1. Core are: honesty, discipline, responsibility, (2. Work ethic: Hard work, simple, self-contained, (3 Attitude: fair, courageous, caring. (Caturwulandari, Goddess; Budi, Astri ; 2017), Anti-corruption education starts by instilling moral values to children can't be done with the commands and prohibitions. Instilling moral values is supposed to raise 
awareness in children Kihajar Dewantara stressed the importance of adult set an example for children. In terms of research in teachers and parents to be models. In accordance with its mandate, "Ing Ngarso Sung Tulodo, Ing Madyo Mangun Karso, Wuri Handayani Tut. "(In front of an example, in the middle of giving guidance, on the back of encouraging). In the anti-corruption education in kindergarten DEK besides learning media wear, children made to feel comfortable when children do wrong, the child does not immediately scold. When admitting guilt, give appreciation. Make the child feel that being honest was fun (being honest feels good). In instilling the values of honesty effectively, teachers need to understand the knowledge about how to cultivate honesty and honesty in the child, as well as knowledge on how to communicate effectively with children. After collecting data on anti-corruption learning with various media in kindergarten DEK Padang. The results with the data in the table 1 .

Table 1. Learning Media used in the Anti-Corruption Education

\begin{tabular}{|lll|}
\hline \multirow{2}{*}{ Instructional Media } & \multicolumn{2}{l}{$\begin{array}{l}\text { Frequency of Use in } \\
\text { 1 Month }\end{array}$} \\
\cline { 2 - 3 } & class 1 & Grade 2 \\
\hline board Games & 1 & 10 \\
\hline $\begin{array}{l}\text { Contained Story Books } \\
\text { anti-corruption education }\end{array}$ & 8 & 10 \\
\hline Songs values anticorruption & - & 31 \\
\hline $\begin{array}{l}\text { Video (watch movies planting } \\
\text { The values of anti-corruption }\end{array}$ & 4 & 4 \\
\hline $\begin{array}{l}\text { Publication brave companions } \\
\text { Puzzle Commission }\end{array}$ & 1 & - \\
\hline
\end{tabular}
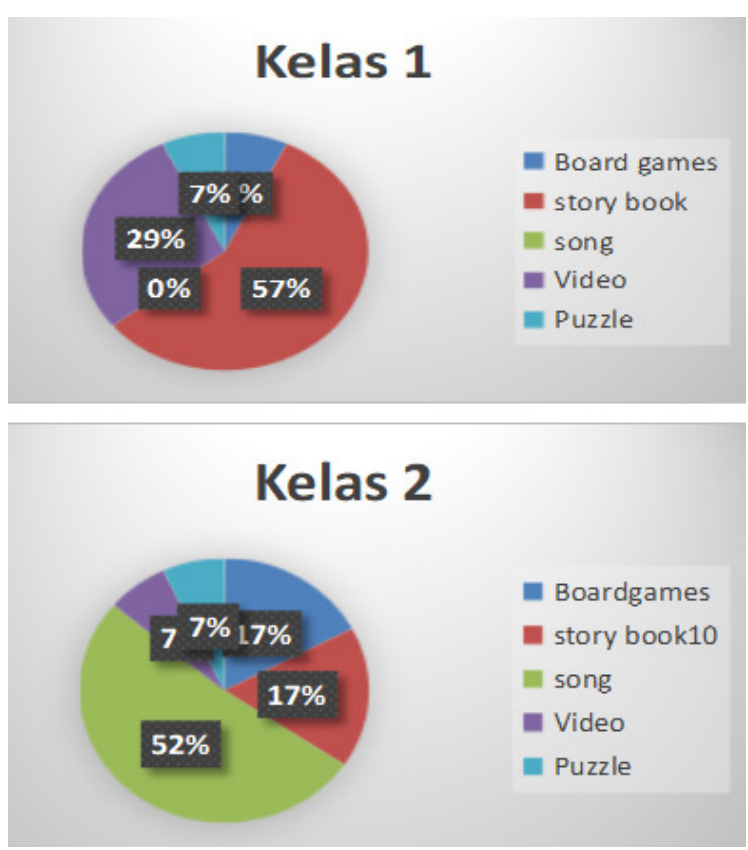

Figure 1. Aanticorruption media usage in 1 Month
The results showed that each class using a different medium frequencies, according to the ability of teachers and the interests of children. Of the children of observation data more easily perform anticorruption character with storytelling and song forms. From the data observations and parent interviews that anticorruption learning media using the media picture books and songs can embed their anticorruption code can be reminders of friends and oaring adult if telling a lie. They sang a song containing advice should not lie when friends or others are lying. Similarly, the anticorruption values contained in the picture story. More easily embedded in children.

Through the activities of anti-corruption program that is carried out continuously, integrated with instructional materials in kindergarten then primary goal in the planting of anti-corruption code can be executed. Anticorruption learning through observation we can make a change in character through honesty indicators of children aged 4-6 years are (1. Distinguish between their own and their stuff together, (2. Request permission when going to borrow other people's stuff. (3. Say something actually occurred, (4 Admitting mistakes, (5. apologize when wronged and forgive the guilty friend, (6. do not exchange the items belonging to himself with someone else without permission, (7. do not cheat. the results of the analysis of the data the frequency of the use of instructional media corruption, frequency class of continuous learning with a variety of media, shows that children who have introduced anti-corruption values better understand and be able to practice it. From the data analyzed two classes of class turns into knowledge and action are two behaviors based on the values of anticorruption appropriate indicators mentioned above, children are more familiar than classroom knowledge into two frequencies is less common in first class.

In addition to anti-corruption learning to use the media, also uses communication techniques to build a positive image. in communication, teachers must demonstrate gestures, body language, expression, choice of words, and words that are easily understood by children. Build empathy private teacher should be empathetic and care about their feelings. Children who understand that he accepted and understood will be easier to accept and understand others. But on the contrary if the teacher shows the attitude harass another person, for example in front of children do not appreciate the work of others, the child will assume the right attitude. Respect for others is the basis of honesty.

Some attitudes also been applied to the study of anticorruption in kindergarten DEK developing empathy in children include: teachers encourage children to talk about the feelings of others. For example, "Chloe sad when you do not play. How can he not sad anymore? "Then the teacher tried to get the child to empathize with other people in a way," Let's take Chloe to play so she was not sad anymore. "Or with the phrase" How can he not sad anymore? '. Furthermore, the class teacher shows the child that attitude and negative feelings such as anger, sadness, hate was reasonable. Kids may not express it, but should refrain from disturbing or harming others. Teachers usually teach restraint attitudes through song or poem with a verse like this example: "If I'm angry, I entered the room, sit quietly, 
breathe in length. Says I'm angry, said I was upset, no need o'clock because my dear friend.(Caturwulandari, 2015).

To inculcate honesty not only through the media, through habituation and become an exemplary figure. Teachers do not get used to lying when persuading a child. Teachers have omitted the word -word containing elements lie like this, "If you do not want to eat I'll call the police.". Telling children paragon who do honest or national heroes who have done an honest or honest story of Mohammad Hatta and simple while he covet bally shoes. Through this activity, children will be embedded if it is very important to live honestly. Learning corruption cannot be separated only in the classroom but during the play we can have a dialogue with the appropriate words of reason children with simple language. Teachers have a lot of vocabulary in guiding children's behavior such activities do not cheat.

\section{CONCLUSION}

Based on the above discussion it can be concluded that the anti-corruption education can be designed and implemented in early childhood by taking into account the characteristics of early childhood. The role of a teacher and the learning environment is very important in anticorruption, can not be replaced by machines, because the learning anticorruption should use caution, possessed by man who is honest and sincere. Learning success in the anticorruption education should have a program to be more focused and goal to be achieved with programs that support learning activities for early childhood anticorruption. So it is advisable for future researchers to make book learning support for early childhood corruption. This is important since the days it was a strong character foundation plantings.

\section{ACKNOWLEDGMENTS}

Researcher would say thanks to the head of kindergartens DEK which has provided the opportunity to hold this study, teachers who have helped and provide data observations, as well as parents who responded on learning the importance of anti-corruption education. Thanks also to the Corruption Eradication Commission for facilitating media and story books and boards games as well as films that contain payloads sikumbi series of anticorruption education., So it helps the learning process.

\section{REFERENCES}

[1] Abramov, Ruslan A; Sokolov, Maxim S ;. (2016). And Methodology Theoretical Aspects Of The Formation Of Anti-Corruption Mechanisms in The System Of Higher Education Of The Russian Federation. International Journal Of Environmental \& Science Education, 11.

[2] Anttiroiko, AV (2014). Good Government In Context: Learning From the Anti-Corruption
Policies Of Finland And Singapore. University of Tampere. Munich Personal RePEc Archive. Retrieved from https://mpra.ub.uni$\underline{\text { muenchen.de/67807/ }}$

[3] Arikunto, Jabar. (2008). Jakarta Education Program Evaluation:. PT Bumi Literacy.

[4] Assegaf, AR (2015). And Educational Policy Analysis For Anti-Corruption Strategy IN Indonesia And Singapore. International Journal of Asian Social Science.

[5] Bungin, B. (2011). Quantitative Research Methodology. Jakarta: Kencana Prenada Media Group.

[6] Caturwulandari, D. (2015). Teacher Creativity Potential ECD hone in Creating Songs, Poems and Stories For Early Childhood (SebuahPenuturan Descriptive of Teachers early childhood experience Gagas Ceria). International Conference on Children's Issues, 6.

[7] Caturwulandari, Goddard; Budi, Astri ; (2017). Sowing Seeds of Integrity. Jakarta: The Corruption Eradication Commission Directorate for Education and Human Services.

[8] Dewayanti, S. (2016). I was Honest Kids. The Corruption Eradication Commission, Directorate for Education and Human Services.

[9] Indrawati, N. (2015). The Development of AntiCorruption Education Course for Primary School Teacher Education Student. Journal of Education and Practice, 6.

[10] Manurung, RT (2012). As the Anti-corruption education and Humanistic Character Education Unit. Sosioteknologi Journal, 232.

[11] Mayar, F. (2013). Early Childhood Social Development Seed For The Future For Nation. AlTa'lim Journal, 459-465.

[12] Montessori, M. (2012). As the Anti-corruption education Character Education In Schools. Journal of Democracy, 11.

[13] Riduwan. (2009). Easy Learning Research For Teachers Employees and Research starters. , Bandung: Alfabeta.

[14] Suryana, D. (2013). Early Childhood Education (Theory and Practice Learning. Padang: UNP Press Padang. 
[15] Suryana, D. (2017). Scientific Thematic Approach Based Learning In Kindergarten. Journal of Early Childhood Pendidkan, 11.

[16] Law No.30 / 2002 on Corruption Eradication Commission. $(\mathrm{Nd})$. KPK.

[17] Werdiningsih, Rini ; (2016, November). Integrating Schools And Family Cultures In Anti-Corruption Character Education. IQSR Journal of Humanities And Social Science (IQSR-JHSS), 21 (11, Ver.2), 24-25. Retrieved from www.iosrjournals.org 